American Journal of Animal and Veterinary Sciences 4 (4): 85-91, 2009

ISSN 1557-4555

(C) 2009 Science Publications

\title{
Improving Performance of Replacement Heifers in Hot Arid Environment Under Intensive Management
}

\author{
M. A. Razzaque, S. A. Mohammed, T. Al- Mutawa and M. Bedair \\ Department of Aridland Agriculture and Greenery, \\ Kuwait Institute for Scientific Research, P.O. Box 24885, Safat 13109, Kuwait
}

\begin{abstract}
Problem statement: Imported Holstein Friesian dairy cattle are exposed to hot arid climate in feedlot management in Kuwait. Desert climate is extreme reaching high $45-50^{\circ} \mathrm{C}$ in summer and low $-4^{\circ} \mathrm{C}$ in winter at day and night respectively. High calf mortality, poor reproduction and milk yields were main constraints to viable dairying. The objectives of this study were to assess the magnitude of calf mortality, its causes; implement strategic intervention measures for improving calf survival rates and evaluate dairy herd performance. Approach: Two scenarios were used: (1) studying dairy herd performance without applying intervention measures and (2) introducing improved management with interventions. Performance of the herds of situations 1 and 2 were compared. Three classes of dairy herds, pre-weaned calves, heifers and first lactation cows born in Kuwait were used. Results: Implementing intervention measures resulted in significant $(p=0.001)$ reduction of crude calf mortality rates from a mean of $43.6 \%$ to a low $4.67 \%$. Growth rates of calves and heifers increased significantly, resulting in breeding of locally raised heifers at 15 mo age instead of usual practice of breeding at 18-22 mo. Feed cost was significantly reduced by $14-25 \%$ by early breeding of heifers. Herd culling rate was reduced from $62-33 \%$ and conception rates increased by $41 \%$. The milk yield was increased by $1.25-1.50$ fold through replacing the imported cows by locally born heifers. Adult cattle mortality rates reduced from high 9 to a low $1 \%$. Case study showed that locally born and reared dairy herd formed a mean of $65.8 \%$ of total dairy cattle in cooperating farms. Conclusion: A systematic applied research studies in the commercial dairy farms had resulted in a visible improvement in the performance of all categories of locally born dairy herds and they were better adapted to the local hostile climate.
\end{abstract}

Key words: Dairy calf, heifer, feedlot, intervention, performance

\section{INTRODUCTION}

Milk yield of imported Holstein Friesian dairy cows exposed to Kuwait's hot feedlot environment ranged from 2,500-4,500 liters milk/cow/lactation. Mean life-time performance of cows was low i.e., 2.3 lactations $/ \mathrm{cow}^{[1]}$. The constraints adversely affecting the performance of dairy cattle in Kuwait were assessed $^{[2]}$. They found that the fundamental problem was that the country did not have traditional local dairy cattle breed adapted to the local harsh arid environment. The calves born from exotic dairy cows had a very high mortality rate ${ }^{[3]}$, therefore, the producers were unable to raise their replacement heifers and adapt them for milk production.
Assessments carried out ${ }^{[4]}$ revealed that nutritional and health management of all classes of dairy herds were inadequate causing poor growth of calves, below standard reproductive efficiency and milk yield of imported cattle. Gwatibaya et al. ${ }^{[5]}$ and Amani et al. ${ }^{[6]}$ observed that heat stress had a significant adverse effect on milk yield and reproductive efficiency in cows in Zimbabwe and Sudan. However, improved nutritional status of cows in hot arid conditions in Kuwait had resulted in improved milk yield and reduced feed $\cos ^{[1]}$. Studies carried out in Arizona, USA by Ray et al. ${ }^{[7]}$ found that there was a significant influence of seasons and microclimate on fertility of dairy cows. An eight year duration study was conducted in the commercial dairy farms of Kuwait to

Corresponding Author: M.A. Razzaque, Department of Aridland Agriculture and Greenery,

Kuwait Institute for Scientific Research, P.O. Box 24885, Safat 13109, Kuwait

Tel: +965 24989840 Fax: +965 24989809 
evaluate the performance of young growing dairy under two situations, with and without interventions.

\section{MATERIALS AND METHODS}

Investigations were carried out over a period of 8 years in phases in the commercial dairy farms of Kuwait. The studies concentrated on surveying the Kuwait's dairy farms for assessing the magnitude of pre-weaned calf mortality and identifying its causes, rearing the replacement heifers, adapting them to local environment and evaluating their performance.

Study location and climate: The dairy farms were located in Sulaibiya, $25 \mathrm{~km}$ northwest of Kuwait city and managed in feedlot system (zero grazing). Summer season extending from June to early September is mostly dry with extremely hot daytime temperature of $48^{\circ} \mathrm{C}$. After last part of July, temperature reaches as high as $50^{\circ} \mathrm{C}$ for $1-2$ weeks with dry air and a low Relative Humidity (RH). RH increases after mid August and September reaching over $90 \%$ with simultaneous decline of temperature, reaching $40-43^{\circ} \mathrm{C}$ during early September. Autumn season extends over October and November, decreasing temperature to 30 and $20^{\circ} \mathrm{C}$ respectively. Winter season extends from December to February and part of March during which, temperature can reach as low as $-4^{\circ} \mathrm{C}$ at night and high $10-19^{\circ} \mathrm{C}$ at day. Spring season covers part of March to May temperatures reaching $20-30^{\circ} \mathrm{C}$.

Calf mortality and its causes: Retrospective data: Calf mortality data of a complete year were extracted from the database of the PAAFR ${ }^{[8]}$ which included number of calves born, died and sold from all farms of Kuwait. Crude mortality rate was calculated by the formula ${ }^{[9]}$ :

Crude mortality rate $=$ No. of calf deaths divided by average number of calves at risk (opening number of calves + closing number of calves/2) $\times$ internal time component

Field survey: For the field survey work, the dairy farms were classified as large ( $>500$ head), medium (250-499 head) and small ( $<250$ head) farms. Twelve farms, 4 from each class were randomly selected from all Kuwait's 29 farms that reared calves. Stratified sampling procedures within herds using proportional allocation were adapted representing $56 \%$ of the total 11,760 dairy milking cow population of Kuwait. A survey format was used to record individual calf data for the 1,280 calves $^{[3]}$. Each dairy farm was visited on a regular basis for data collection of new born calves.
Causes of calf mortality: Survey work involved identification of causes of calf morbidity and mortality from disease histories, clinical symptoms and laboratory microbiological studies. Biological samples from sick calves and from calves after post-mortem examination were collected. Fecal samples were collected from calves showing the symptoms of diarrhea and dehydration. Nasal swabs and blood samples were screened according to standard procedures for respiratory diseases ${ }^{[10]}$.

Strategy for improving herd performance: On completion of the field survey, a strategy was developed to address the key constraints identified during the survey studies. The main strategy elements of the interventions were implemented in dairy farms of Kuwait as shown in Table 1.

Without interventions: In without intervention situation (control) the dairy cattle production system followed the commercial practices of the farms without applying extra management.

Intervention measures: According to the strategy, two scenarios of dairy cattle production systems were compared. In with intervention situation, the calves were housed in newly introduced hutches for feeding and health management. Improved feeding and quick treatment for calf-hood diseases was followed (Table 1).

Calf housing and feeding: Clean environment for calving cows, timely and clean colostrum feeding were ensured. Immune status of calves was monitored through determination of immunoglobulins ( $\mathrm{IgG}, \mathrm{IgM}$ and $\operatorname{IgA}$ ) of $36 \mathrm{~h}$ old calves. One of the elements of the strategy of pre-weaned calf rearing was introduction of individual polyvinyl calf hutches. Hutches had ultraviolet blocking pigments to prevent heat build up and enabling natural ventilation and easy to clean ${ }^{[2]}$. These hutches were used year-round. Clean sand bedding was used in the hutches to maintain hygien ${ }^{[2]}$. Mortality rates were monitored from $90 \mathrm{~d}$ age till their calving and lactation stages.

Nutrition of dairy herds: Nutritional trial was conducted to compare the performance of heifers fed with commercial diets (control-C), without added supplement and improved supplemented diets (Treatment-T) having balanced nutrients ${ }^{[11]}$. A total of 168 heifers (72 $\mathrm{C}$ and $96 \mathrm{~T}$ herds) were used for the study and they were fed diets (Table 2) twice daily with ad libitum fresh water supply ${ }^{[11]}$ and their live weight gain and heights were monitored. The heifers were vaccinated against FMD, Rinderpest, Brucellosis, Rift Valley Fever and IBR. 
American J. Animal \& Vet. Sci., 4 (4): 85-91, 2009

Table 1: Strategy elements and intervention actions for improving pre-weaned calves, heifers and cows

\begin{tabular}{|c|c|}
\hline Strategy elements & Intervention actions \\
\hline \multicolumn{2}{|l|}{ Pre-weaned calves } \\
\hline Recording system for calves & Established a system for individual calf events. \\
\hline Pre-calving management of heifers and cows & $\begin{array}{l}\text { Ensured a clean environment without fecal contamination and contact of late pregnant heifer cows } \\
\text { with pathogens. }\end{array}$ \\
\hline Colostrum feeding & Implemented colostrum feeding from cows or from colostrum bank. \\
\hline Calf housing & $\begin{array}{l}\text { Provided a clean housing and feeding environment to reduce disease threat. Provided dry and } \\
\text { disinfected calf pen or calf hutch. }\end{array}$ \\
\hline Heifers & Formulated balanced diet and introduced ideal feeding method for weaning of calves at 3 mo. \\
\hline Selection of replacement heifers & $\begin{array}{l}\text { Selected weaned heifer calves at } 3 \text { mo. of age. Recorded weights, heights and vaccinated. Provided } \\
\text { balanced ration and adequate dietary fibers. }\end{array}$ \\
\hline Heifer management: weaning to $12 \mathrm{mo}$ of age & $\begin{array}{l}\text { Fed diets to achieve growth rate, weights, heights and body conditions. } \\
\text { Selected and culled heifers to minimize feed/labor costs. } \\
\text { Separated the potential heifers and grouped them according to body conditions. }\end{array}$ \\
\hline Heifer management: $15-18$ mo. of age & $\begin{array}{l}\text { Monitored reproductive behavior, synchronized estrus if on-time and mating as planned. } \\
\text { Introduced fixed time artificial insemination (AI). Natural breeding through a closed observation. }\end{array}$ \\
\hline \multicolumn{2}{|r|}{ 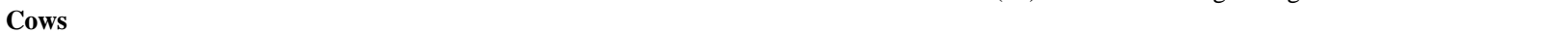 } \\
\hline Management during pregnancy and delivery & Applied nutritional practices to meet the requirements of pregnancy. \\
\hline Management of lactating cows & Formulated rations according to recommended feed composition and req \\
\hline \multirow[t]{2}{*}{ Herd health management and bio-security } & $\begin{array}{l}\text { Provided rations according to the milk yield, weight and stage of lactation. } \\
\text { Used bio-security measures as per standard farm operating procedures. }\end{array}$ \\
\hline & $\begin{array}{l}\text { Ensured veterinarian care of the herd on a routine basis for identification of mastitis cases, laminitis, } \\
\text { bloats and sick animals. }\end{array}$ \\
\hline Feeds, feeding and nutrition of herds & $\begin{array}{l}\text { Selected feed ingredients and mixed feeds based on quality, routine analysis and nutritional } \\
\text { evaluation. Avoided drastic changes of rations for all herds. }\end{array}$ \\
\hline Body Condition & Maintained body conditions of heifers and cows. \\
\hline
\end{tabular}

Table 2: Composition* of concentrate mixtures of different classes of dairy herds: Control and treatment herds

\begin{tabular}{|c|c|c|c|c|c|c|}
\hline \multirow[b]{2}{*}{ Classes of dairy herds } & \multicolumn{6}{|c|}{ Percentage on dry matter basis } \\
\hline & DM\% & Ash & $\mathrm{CP}$ & $\mathrm{EE}$ & NDF & ADF \\
\hline \multicolumn{7}{|l|}{ Control (without I) } \\
\hline Pre-weaned calves & 0.4 & 3.1 & 12.1 & 3.3 & 28.8 & 9.3 \\
\hline Wean & & 4.2 & & 3.9 & 1.0 & 7.1 \\
\hline Grov & 2.5 & 5.3 & 10.9 & 3.0 & 27.7 & 7.0 \\
\hline Pregn & & 3.6 & & 2.8 & 36.9 & 14.4 \\
\hline Milk c & 0.3 & 7.5 & 15.1 & 2.2 & 31.7 & 11.8 \\
\hline Dry cows & & 6.8 & 11.3 & 2.4 & 38.8 & 15.2 \\
\hline \multicolumn{7}{|l|}{ Treatment } \\
\hline Pre- $\downarrow$ & 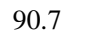 & 5 & & 3.2 & 2 & 9.2 \\
\hline & 90.2 & 9.6 & 17.2 & 2.4 & 25.9 & 8.6 \\
\hline & 89.9 & N/A & 16.9 & N/A & 30.5 & 10.7 \\
\hline Pregnant heifers $(\mathrm{N} 5 \times 3)$ & 91.2 & 7.3 & 17.3 & 2.8 & 24.3 & 6.5 \\
\hline Milk cows $(\mathrm{N} 6 \times 3)$ & 91.2 & 6.4 & 17.5 & 2.8 & 28.6 & 12.4 \\
\hline Dry cows $(\mathrm{N} 1 \times 3)$ & 90.0 & 8.1 & 17.7 & 3.3 & 29.1 & 7.6 \\
\hline
\end{tabular}

I: Intervention; *: Mean values of triplicate analysis; N/A: Not Analyzed; Pre-weaned calves: 0-3 mo; Weaned heifer calves: 4-6 mo; Growing Heifers: 7-15 mo; Pregnant heifers: 16-24 mo; Milk cows (1st lactation): $25-33 \mathrm{mo}$

Reproduction and breeding: Heifers attaining the target growth parameters $(132 \mathrm{~cm}$ height and $385 \mathrm{~kg}$ live weight) were assigned to breeding groups to facilitate heat detection and mating. Heat mount detectors were affixed for oestrus detection. Heifers were synchronized with two Prostaglandin $F_{2}$ alfa $\left(\mathrm{PGF}_{2 \mathrm{a}}\right)$ injections (Preloban produced by Intervet, European Union) $11 \mathrm{~d}$ apart ${ }^{[12]}$. They were Artificially
Inseminated (AI) $72 \mathrm{~h}$ after the second injection. Pregnancy diagnosis was carried out by rectal palpation on the 40th day. Breeding performance was determined by estrus detection rate (number of animals observed in heat divided by the number of animals in breeding cohort under observation $\times 100$ ), estrus intervals (number of days between successive estrus), submission rates (number of animals bred divided by the number of animals due to be bred over the first 20 days after breeding is due to commence, in percentage). First service conception rates (number of animals confirmed pregnant to the 1 st service divided by the number of animals serviced $\times 100$ ).

Immunization of pregnant cows: Pregnant cows and heifers were administered Lactovac vaccine (Intervet UK Ltd) against E. coli, Rotavirus and Coronavirus. They received two injections of $5 \mathrm{~mL}$ vaccine during their late pregnancy with an interval of 4 and 5 weeks between the doses and allowing 2 and 3 weeks from the time of the 2nd dose until the planned date of calving. A total of 720 and 357 calves were born from vaccinated and unvaccinated dams respectively. The pregnant heifers or cows were brought to disinfected calving area. A total of 133 calves from their birth to 90 days age were individually recorded for their disease syndromes to identify the causes of diseases. 
Feeding trial on lactating cows: First lactation cows were randomly divided into $\mathrm{T}$ and $\mathrm{C}$ groups. The $\mathrm{C}$ herd was provided with commercial concentrate mixers and $\mathrm{T}$ herd fed with concentrate mixture formulated according to the $\mathrm{NRC}^{[11]}$ standards (Table 2). Herd management was similar for both the groups. The roughage to concentrate ratios were 20: 80 for both $\mathrm{C}$ and $\mathrm{T}$ herds comprising $10 \%$ alfalfa hay $10 \%$ wheat straw. Both concentrates and roughages were analyzed $^{[13,14]}$. Feed intake and costs were compared.

Milk yield and analysis: Daily records of total milk production of first lactation cows of both $\mathrm{C}$ and $\mathrm{T}$ groups of 65 and 82 cows respectively were recorded. A portable milk analyzer "Lactoscan" (Manufacturer: Milkotronic Ltd, European Union, Bulgaria) was used for determination of fat, protein, Solid Non Fat (SNF), lactose, density and water content.

Serum immunoglobulins: A colostrum bank was established so that the calves receive adequate quantity of clean colostrum on time. The level of Immunoglobulins (Ig) (IgG, IgM and $\operatorname{IgA}$ ) of blood serum of calves of $3 \mathrm{~d}$ old were determined ${ }^{[15,16]}$.

\section{RESULTS}

Causes of calf morbidity, mortality and growth rate of Pre-weaned calves: Major disease syndromes of sick calves were diarrhea, pneumonia, pneumo-enteritis (Table 3). Diarrhea was found in calves of ages between 1-15 d; whereas, most cases of pneumonia and pneumo-enteritis were found in calves of ages between 16-60 d. Pneumonia associated with pneumo-enteritis accounted for $68.4 \%$ of total disease syndromes. Clinical Laboratory diagnosis showed that main causal agents of diarrhea/enteritis were Escherichia coli, Salmonella, Klebsiella, Rotavirus, Coronavirus, Cryptosporidia and Coccidia and that of Pneumonia Staphylococcus, Streptococcus and Pasteurella sp. (Table 4). The risk rates for the diseases caused by these organisms ranged from 20-100\%. Parasites detected were Cryptosporidia and Coccidia sp.
The crude mortality rates of pre-weaned calves born from vaccinated and unvaccinated dams were $12.8 \%$ and $12.1 \%$ respectively (table not presented). At the start of the study, crude calf mortality rate was as high as $90 \%$ (mean $43.63 \%$ ) and then reduced by introducing intervention measures to as low as $2 \%$ (mean 4.67\%). Phase-wise reduction of crude mortality was highly significant during 8 year study period (Fig. 1). Improved diet and hutch housing of calves resulted in a significant $(p=0.01)$ improvement in daily gain (Table not presented) compared to control $\left(523{\mathrm{~g} \mathrm{Vs} 115 \mathrm{~g}_{\text {gain }}}^{-1}\right.$ day $\left.^{-1}\right)$.

Heifer growth: Heifers of $\mathrm{T}$ diet achieved significantly $(\mathrm{p}=0.001)$ better growth rates than animals on the $\mathrm{C}$ diet (Table 5). The proportion of heifers (89\%) reached the target height $(127 \mathrm{~cm}$ at $12 \mathrm{mo}$. of age) in $\mathrm{T}$ compared to $\mathrm{C}(15 \%)$ and $74 \%$ and $30 \%(\mathrm{p}=0.001)$ of the target weight (336 kg at $12 \mathrm{mo}$. age) in T and C respectively. Significant differences $(\mathrm{p}=0.001)$ in daily live weight gains were observed between $\mathrm{T}$ and $\mathrm{C}$ herds of farms 2 and 3. Regression analyses showed that there was a significant positive correlation between the weaning weights and weight at 12 mo. of heifers $\left(r^{2}=6825, p=0.01\right)$.

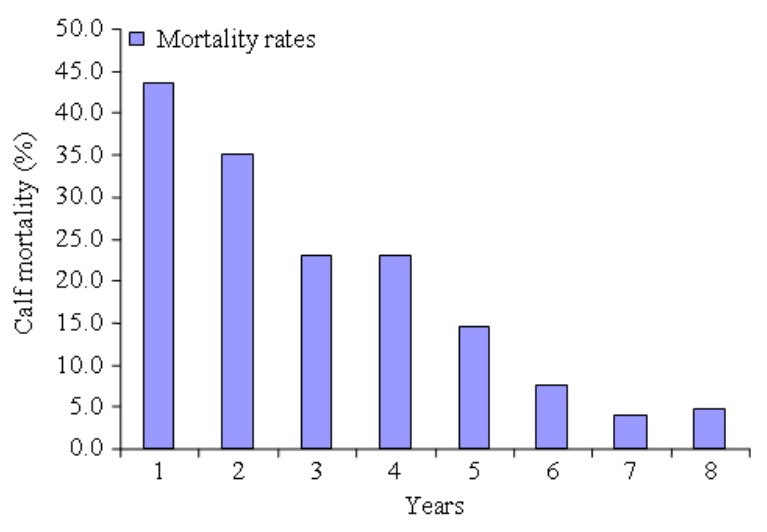

Fig. 1: Phase-wise reduction of crude mortality (\%) from years 1-8. (Year 1) Retrospective data; Year 2: Field survey data; (Years 3-8) Intervention measures implemented

Table 3: Disease syndromes and deaths by age groups (numbers) in pre-weaned calves

\begin{tabular}{llccccccc}
\hline Age $(\mathrm{d})$ & Colic & Diarrhea & Joint illness & Pneumonia & Pneumo-enteritis & Surgery & Tympani & Total \\
\hline $1-7$ & 0.0 & 2.0 & 0.0 & 1.0 & 9.0 & 8.0 & 0.0 & 20.0 \\
$8-15$ & 2.0 & 7.0 & 0.0 & 1.0 & 9.0 & 0.0 & 0.0 & 19.0 \\
$16-30$ & 1.0 & 1.0 & 11.0 & 14.0 & 13.0 & 12.0 & 0.0 & 1.0 \\
$31-60$ & 0.0 & 0.0 & 5.0 & 14.0 & 3.0 & 4.0 & 1.0 & 43.0 \\
$61-90$ & 2.0 & 0.0 & 1.0 & 5.0 & 0.0 & 0.0 & 0.0 & 24.0 \\
$>90$ & 0.0 & 10.0 & 17.0 & 41.0 & 46.0 & 0.0 & 0.0 & 6.0 \\
Totals & 5.0 & 7.5 & 12.8 & 33.8 & 34.6 & 12.0 & 2.0 & 133.0 \\
Proportion $(\%)$ & 3.8 & & & & & 9.0 & 1.5 & 100.0 \\
\hline
\end{tabular}


American J. Animal \& Vet. Sci., 4 (4): 85-91, 2009

Table 4: Laboratory diagnosis of bacterial, viral and parasitic diseases of pre-weaned calves

\begin{tabular}{lccc}
\hline Microbial species & $\begin{array}{l}\text { No. of } \\
\text { samples }\end{array}$ & $\begin{array}{l}\text { No. } \\
\text { positive }\end{array}$ & $\begin{array}{l}\text { Morbidity } \\
\text { risk rate (\%) }\end{array}$ \\
\hline Diarrhea and enteritis agents & & & \\
Escherichia coli & 24 & 10 & 41.67 \\
Salmonella & 34 & 11 & 32.35 \\
Klebsiella & 28 & 8 & 20.57 \\
Rotavirus & 5 & 3 & 60.00 \\
Coronavirus & 10 & 10 & 100.00 \\
Cryptosporidia & 23 & 15 & 65.21 \\
Coccidia & 5 & 1 & 20.00 \\
Pneumo agents & & & \\
Staphylococcus & 10 & 10 & 100.00 \\
Streptococcus & 10 & 10 & 100.00 \\
Pateurella & 10 & 10 & 100.00 \\
\hline
\end{tabular}

Table 5: Heights, Weight and Daily Live Weight Gain of Heifers in three farms

\begin{tabular}{|c|c|c|c|c|c|c|}
\hline \multirow[b]{2}{*}{ Variables } & \multicolumn{2}{|l|}{ Farm 1} & \multicolumn{2}{|l|}{ Farm 2} & \multicolumn{2}{|c|}{ Farm 3} \\
\hline & $\mathrm{T}$ & $\mathrm{C}$ & $\mathrm{T}$ & $\mathrm{C}$ & $\mathrm{T}$ & $\mathrm{C}$ \\
\hline No. heifers & 19.00 & 13.00 & 38.00 & 8.00 & 10.00 & 4.00 \\
\hline $\begin{array}{l}\text { No. reaching height } \\
\text { standard }\end{array}$ & 17.00 & 2.00 & 11.00 & 3.00 & 5.00 & 0.00 \\
\hline *Proportion (\%) & $89.00^{\mathrm{a}}$ & $15.00^{\mathrm{b}}$ & $31.00^{\mathrm{a}}$ & $38.00^{\mathrm{a}}$ & 50.00 & 0.00 \\
\hline $\begin{array}{l}\text { No. reaching weight } \\
\text { standard }\end{array}$ & 14.00 & $3 / 10$ & 7.00 & 1.00 & 1.00 & 0.00 \\
\hline Proportion $(\%)$ & $74.00^{\mathrm{a}}$ & $30.00^{\mathrm{b}}$ & $19.00^{\mathrm{a}}$ & $13.00^{\mathrm{b}}$ & 10.00 & 0.00 \\
\hline Mean ADG (kg) & $1.16^{\mathrm{a}}$ & $0.94^{\mathrm{a}}$ & $0.81^{\mathrm{a}}$ & $0.68^{\mathrm{b}}$ & $0.67^{\mathrm{a}}$ & $0.52^{b}$ \\
\hline
\end{tabular}

Reproductive performance of heifers: Ages of heifers were approximately 13-15 mo while clear cycling occurred. Only those heifers that attained the standard growth value of $132 \mathrm{~cm}$ in height and were $>380 \mathrm{~kg}$ body weight were mated by AI.

Comparing herd performance: In the commercial system of management (without intervention), adult dairy herd crude mortality was found high (Table 6). The mortality rate was significantly reduced 9 Vs $1 \%$. Likewise, an annual culling rate of herd was reduced from $66-33 \%$. Milk yield improved in first lactation cows born in Kuwait by 1.25-1.5 fold.

Contribution of growing locally born and raised dairy cattle to total herd: A case study: As a result of continued applied studies first to third lactation cows formed 32\% of the total cows (Table 7), a higher proportion of locally pregnant (59\%) and growing heifers (97.8\%) contributed to the total young heifers. Above locally born replacement heifers were better adapted to the Kuwait's environment for breeding milk production compared to imported herds.
Table 6: Comparative performance of young and mature dairy herds with and without research interventions

\begin{tabular}{|c|c|c|c|}
\hline \multirow[b]{2}{*}{ Variables } & \multicolumn{2}{|c|}{ Interventions } & \multirow{2}{*}{$\begin{array}{l}\text { Improvement } \\
\text { level }\end{array}$} \\
\hline & With & Without & \\
\hline Calves mortality rate $(\% 0-3 \mathrm{mo})$ & $4.67^{\mathrm{a}}$ & $43.63^{\mathrm{b}}$ & $9.3 \mathrm{x}$ \\
\hline Weight gain calves $\left(0-3 \mathrm{mo} \mathrm{g} \mathrm{h}^{-1}\right.$ day $\left.^{-1}\right)$ & $523^{\mathrm{a}}$ & $115^{\mathrm{b}}$ & $4.5 \mathrm{x}$ \\
\hline Heifers standard height $(\%)$ & $89^{\mathrm{a}}$ & $15^{\mathrm{b}}$ & $5.9 \mathrm{x}$ \\
\hline Heifers standard weight (\%) & $74^{\mathrm{a}}$ & $30^{\mathrm{b}}$ & $2.4 \mathrm{x}$ \\
\hline Breeding of heifers (mo) & $15^{\mathrm{a}}$ & $18-22^{\mathrm{b}}$ & $\begin{array}{l}\text { Saved feed } \\
\text { cost by } 25 \%\end{array}$ \\
\hline Calving age of heifers (mo) & 24 & $25-31$ & $\begin{array}{l}\text { Saved feed } \\
\text { cost by } 14 \%\end{array}$ \\
\hline Adult herd mortality rate $(\%)$ & $1^{\mathrm{a}}$ & $9^{\mathrm{b}}$ & $9.0 \mathrm{x}$ \\
\hline Herd culling rate/annum $(\%)$ & $33^{\mathrm{a}}$ & $62^{\mathrm{b}}$ & $1.8 \mathrm{x}$ \\
\hline Milk yield Liters/head/day year 1 & $16.07^{\mathrm{a}}$ & $10.65^{\mathrm{b}}$ & $1.5 \mathrm{x}$ \\
\hline Year 2 & $16.86^{\mathrm{a}}$ & $21.1^{\mathrm{b}}$ & $1.25 \mathrm{x}$ \\
\hline
\end{tabular}

Different superscripts ${ }^{\mathrm{a}}$ and ${ }^{\mathrm{b}}$ of the same farm are significantly different $(\mathrm{p}=0.05)$

Table 7: Contributions of locally born and raised dairy herds to total dairy herd after five-year interventions: A case study in Kuwait (numbers)

\begin{tabular}{lrrrl}
\hline & & & & $\begin{array}{l}\text { Locally } \\
\text { replaced } \\
\text { (percent of }\end{array}$ \\
& $\begin{array}{l}\text { Local } \\
\text { born }\end{array}$ & Imported & Total & total herd) \\
\hline Herd classes & 194 & 408 & 602 & 32.2 \\
\hline Lactating cows & 101 & 70 & 171 & 59.0 \\
Pregnant hersld (Heifers) & 400 & 9 & 409 & 97.8 \\
Growing heifers (6-15 mo old) & 75 & Nil & 75 & 100.0 \\
*Growing young calves & & & & \\
(3-5 mo old) & 176 & Nil & 176 & 100.0 \\
*Pre-weaned calves 1-90 day old & 26 & 18 & 44 & 59.1 \\
Breeding bulls & 972 & 505 & 1,477 & Mean: 65.80 \\
Total & &
\end{tabular}

*: Young growing calves include both males and females (Sex ratio $1: 1)$

\section{DISCUSSION}

Many countries of hot arid region including Kuwait do not have their own adapted dairy cattle breeds, thus depend on temperate origin imported high yielding Holstein Friesian dairy cattle. Systematic relevant studies and data addressing the constraints faced by the dairy farms of Kuwait and similar hot arid countries are scarce. Present investigations addressed some of the constraints of commercial dairy farms of Kuwait.

Causes of calf-hood diseases: Main causes of high mortality rate in pre-weaned calves were identified. Intervention measures (Table 1) were applied and crude calf mortality rate of calves reduced from mean high of 43.6 to low of $4.67 \%$. Most important element of the success was improving on-farm calf health management, housing and nutrition ${ }^{[2,3]}$. Predominant causal agents of diarrhea, pneumonia and enteritis of day old to 2 weeks calves were quickly identified (Table 3). It was found that calves confined in the metallic crates in intensive closed-type housing system 
was associated with a higher incidence of pneumonia as a result of combined adverse effects of a built-up high $\mathrm{RH} \%$ and pathogens. Housing of calves in individual naturally ventilated polyvinyl hutches had reduced crude mortality rate of calves significantly ${ }^{[2]}$. Immune status of the calves also was vital factor in reducing the disease incidence and death ${ }^{[16]}$.

Weaned heifers: Raising replacement heifers, adapting them to an intensive management under hot arid climate were the main strategic elements (Table 1) in our study. It is worth noting that rearing replacement heifers in the dairy farms of Kuwait had been a very rare practice and elsewhere in many countries due to the high calf $\operatorname{losses}^{[1]}$. Once the results of high calf survival rate were demonstrated recently in the commercial dairy farms, rearing of locally born weaned heifers for herd replacement had been initiated by the dairy producers of Kuwait. It was clear that the weaned heifer calves from their 91 day age had minimum health problem and mortality (Table 6). Disease prevention, nutrition and selection were found to be key strategic elements for improved performance of heifers. Improved dietary management of heifers in two out of the three farms had reflected in their performance parameters (Table 2 and 5). Heights, weights and daily live weight gain of heifers had improved significantly $(\mathrm{p} \leq 0.001)$ in $\mathrm{T}$ compared to $\mathrm{C}$ herds, however, farm to farm variations were observed. These differences were associated mainly with incidence of pneumonia in farms 2 and 3 adversely affecting the heifer performance. Our results were consistent with the findings of similar hot climatic zone $^{[17,18]}$. Improved growth rate of heifers resulted in early breeding them at an average of 15 mo instead of 20 mo. This was a significant achievement resulting in a longer lactation life and saving feed cost by 14-25\% (Table 6). Tanaka et al. ${ }^{[19]}$ also found that nutritional management was the key factor for improving reproduction and milk yield of dairy herds.

Locally born dairy herd performance: Our mediumterm results of 8 year demonstrated that use of USA origin superior frozen semen and AI of imported second to third parity Australian Holstein Friesian cows produced better calves with low mortality rate than that born from the imported pregnant heifers. Upgraded weaned heifers reached the targeted body size for breeding them at earlier age than conventional breeding practice in Kuwait.

The usual practice in Kuwait was importation of pregnant heifers from mainly temperate regions and retain them for an average of 2.3 lactations and then cull them as beef cows. The reason for a short productive life of imported cows was the lack of their adaptation to the hostile local climate ${ }^{[3]}$. Recently, Razzaque et $a l .^{[4]}$ observed that there had been economic benefits to the dairy producers in rearing calves in Kuwait. Israeli Holstein Friesian dairy cattle breed was developed over the years by introducing genetic resources obtained from high yield dairy cattle of Europe and USA. Thus, an annual mean milk yield of Israeli cows was $11,281 \mathrm{~kg} / \mathrm{cow} / \mathrm{lactation}$ and the best cow yielded more than $18,700 \mathrm{~kg}$ lactation $^{-1[20]}$.

Dairy producers of Kuwait started to implement plan for rearing their locally born heifers using the recommended procedures of the present study and as well as with the financial incentives provided by the Kuwait Government. As a result, the commercial farms made progress during past 5-6 years in replacing their imported dairy herds by locally born herds. Case study (Table 7) demonstrated on-farm progress made in adapting the strategy of replacement heifer rearing.

\section{CONCLUSION}

Direct involvement of commercial dairy producers in applied research appeared to be very effective means for phase-wise reduction of calf mortality rates and improvement of performance of heifers and first lactation cows raised under feedlot management in hot arid environment.

\section{ACKNOWLEDGEMENT}

Dairy farms, cattle and input were provided by the Kuwait's dairy producers. The expert advice of Dr. David Scharp is appreciated. Kuwait Foundation for the Advancement of Sciences (KFAS) provided partial financial support for the studies. Technical assistance of Ms. Mini Jacob, Ms. Jaisy Johny, Ms. Shalini Mathew, Ms. Sheeba Jasmine and secretarial work of Ms. Shiji Thomas for the preparation of the paper are highly appreciated and acknowledged.

\section{REFERENCES}

1. Razzaque, M.A., S.A. Mohammed, T. Al-Mutawa and M. Bedair, 2009a. Growth, reproduction and milk yield of holstein friesian heifers born and adapted in Kuwait. Pak. J. Nutr., 8: 1159-1163. http://www.pjbs.org/pjnonline/fin1312.pdf

2. Razzaque, M.A., S. Abbas, T. Al-Mutawa and M. Bedair, 2009b. Performance of pre-weaned calves in confined housing and open environment hutches in Kuwait. Pak. Vet. J., 29: 1-4. http://pvj.com.pk/pdf-files/29_1/1-4.pdf 
3. Razzaque, M.A., S. Abbas and M. Bedair, 2009c. Mortality of pre-weaned calves in Kuwait's dairy herds, its causes and impact of interventions. Internet J. Vet. Med., 5: 1-12. http://www.ispub.com/journal/the_internet_journal _of_veterinary_medicine/volume_5_number_2_42/ article/mortality_of_pre_weaned_calves_in_kuwait _s_dairy_herds_its_causes_and_impact_of_interve ntions.html

4. Razzaque, M.A., M. Bedair, S. Abbas and T.Al-Mutawa, 2009d. Economic impact of calf mortality on dairy farms in Kuwait. Pak. Vet. J., 29: 97-101. http://pvj.com.pk/pdf-files/29_3/97-101.pdf

5. Gwatibaya, S., E. Svotwa and D. Jambwa, 2007. Potential effects and management options for heat stress in dairy cows in Zimbabwe; a review. Elect. J. Environ. Agric. Food Chem., 6: 2066-2074. http://ejeafche.uvigo.es/index.php?option=com_do cman\&task=doc_view\&gid=267\&Itemid=33

6. Amani, Z., A. Gader, M.A. Ahmed, L.M. Musa and K.J. Peters, 2007. Milk yield and reproductive performance of Friesian cows under Sudan tropical conditions. Arch. Tierz. Dummerstorf., 50: 155-164. http://arch-anim-breed.fbndummerstorf.de/pdf/2007/at07p155.pdf

7. Ray, D.E., A.H. Jassim, D.V. Armstrong, F. Wiersma and J.D. Schuh, 1992. Influence of season and microclimate on fertility of dairy cows in a hot-arid environment. Int. J. Biometeorol., 36: 141-145. http://www.ncbi.nlm.nih.gov/pubmed/1399105

8. Razzaque, M.A. 1998. (Personal Communication) Dairy herd performance records. Public Authority for Agricultural Affairs and Fish Resource (PAAFR).

9. Martin, S.W., A.H. Meek, and Willeberg, 1987. Veterinary Epidemiology: Principles and Methods. Iowa State University Press, Iowa Ames, ISBN: 08138-1856-7, pp: 48-76.

10. OIE., 1996. Manual of Standards for Diagnostic tests and Vaccines. 3rd Edn., Office of International Des Epizootics, ISBN: 92-9044-4231, pp: 150-600.

11. National Research Council (NRC), 2001. Nutrient Requirements of Dairy Cattle. 7th Rev. Edn., National Academy Press, Washington DC., USA., ISBN: 0-309-06997-1, pp: 184-314.
12. Xu, Z.Z. and L.J. Burton, 1999. Reproductive performance of dairy heifers after estrus synchronization and fixed-time artificial insemination. J. Dairy Sci., 82: 910-917. http://jds.fass.org/cgi/reprint/82/5/910

13. Anderson, B., T. Mader and R. Grant, 1995. Sampling Feeds for Analyses. Cooperative Extension, Institute of Agriculture and Natural Resources, University of Nebraska, Lincoln. Publication No.G77-331-A. http://digitalcommons.unl.edu/cgi/viewcontent.cgi? article $=1430 \&$ context $=$ extensionhist

14. Association of Official Agriculture and Chemists, (AOAC), 1995. Official Methods of Analysis. 16th Edn., Assoc. off. Anal. Chem., 1: 1-30.

15. Donovan, G.A., I.R. Dohoo., D.M. Montogomery and F.L. Bennet, 1998. Associations between passive immunity and morbidity and mortality in dairy heifers in Florida, USA. Prev. Vet. Med., 34: 31-46. DOI: 10.1016/S0167-5877(97)000603

16. Quigely, J.D., C.J. Kost and T.M. Wolfe, 2002. Absorption of protein and $\operatorname{IgG}$ in calves fed a colostrum supplement or replacer. J. Dairy Sci., 85: 1243-1248. http://jds.fass.org/cgi/reprint/85/5/1243

17. Collier, R.J., G.E. Dahl and M.J. VanBaale, 2006. Major advances associated with environmental effects on dairy cattle. J. Dairy Sci., 89: 1244-1253. http://jds.fass.org/cgi/content/full/89/4/1244

18. Drackley, J.K., S.S. Donkin and C.K. Reynolds, 2006. Major advances in fundamental dairy cattle nutrition. J. Dairy Sci., 89: 1324-1336. http://jds.fass.org/cgi/content/full/89/4/1324

19. Tanaka, H., E. Sanjaya, T. Sudartafi, I. Royani, Herliantien, E. Herwiyanti and O. Parlindungan, 2006. Improvement of dairy cattle reproductive efficiency in Indonesia, Jichi Med. Univ. J., 29: 93-103. http://nels.nii.ac.jp/els/110006457556.pdf?id=ART 0008473844\&type $=$ pdf \&lang $=$ en $\&$ host $=$ cinii\&ord er_no $=\& p p v \_t y p e=0 \& l a n g \_s w=\& n o=1255586082$ $\& c p$

20. Israel Dairy Board, 2009. Facts about the dairy industry in Israel. http://www.icbaIsrael.com/dairyindustry-Israel-2008:pdf 